\title{
Reforming global carbon markets or re-imagining alternative climate solutions and sustainabilities? An analysis of selected NGO strategies in Uganda
}

\author{
Kristen Lyons ${ }^{1}$ \\ Peter Westoby \\ Adrian Nel \\ University of Queensland, Australia \\ University of Kwazulu-Natal, South Africa
}

\begin{abstract}
Carbon markets have emerged globally as a central feature in market based strategies to address the climate crisis. Global trade in carbon is based on the premise that it is possible to reduce global greenhouse gas emissions and stabilise the earth's climate, while at the same time generating new forms of capital accumulation. Amongst carbon market initiatives includes Reduction of Emissions from Deforestation and Degradation (REDD) type projects, that connect peasant and subsistence farmers in the south with northern consumers and industries. These projects are expanding on the African continent, giving rise to social, economic and ecological impacts. In this article we chart the responses of social movements to carbon markets. Through a study of selected NGOs active in carbon market campaigns in Uganda, we examine the strategies and tactics of movements in responding to the expanding carbon economy. Our findings demonstrate NGOs' approaches move between, and across, reformist and rebel (or radical) change agendas. Dominant strategies are directed towards reforming carbon markets and associated forestry governance. Meanwhile, a rebel, or radical change agenda - including rejecting the language and ideology of carbon trade, alongside building autonomous local level rights based movements - emerges in the constrained spaces of both privatised green economic governance and a militarised state. Given the constrained opportunities for radical movement organising, and the frequent institutionalization and limited influence of NGOs, increasing understandings of these radical change agendas and their contributions for re-imagining alternative sustainabilities is significant for scholars, activists and practitioners alike.
\end{abstract}

Key words: Carbon markets, REDD, Uganda, alternative sustainabilities

\section{Résumé}

Les marchés du carbone sont apparus globalement comme un élément central des stratégies basées sur le marché pour faire face à la crise climatique. Le commerce mondial du carbone repose sur le principe qu'il est possible de réduire les émissions mondiales de gaz à effet de serre et de stabiliser le climat de la terre tout en générant de nouvelles formes d'accumulation de capital. Parmi les initiatives du marché du carbone figurent les projets de réduction des émissions provenant du déboisement et de la dégradation (REDD), qui relient les paysans et les agriculteurs de subsistance du Sud aux consommateurs et aux industries du Nord. Ces projets se développent sur le continent africain, donnant lieu à des impacts sociaux, économiques et écologiques. Dans cet article, nous répertorions les résonances des mouvements sociaux sur les marchés du carbone. Grâce à une étude de certaines ONG actives dans les campagnes sur le marché du carbone en Ouganda, nous examinons leurs stratégies et leurs tactiques, et comment elles réagissent à l'expansion de l'économie du carbone. Nos résultats démontrent que les approches des ONGs se déplacent entre les

\footnotetext{
${ }^{1}$ Dr Kristen Lyons, Associate Professor and Dr Peter Westoby, Senior Lecturer; School of Social Science, Faculty of Humanities and Social Sciences, University of Queensland, Australia. Dr. Adrian Nel, Senior Lecturer, Department of Geography, University of Kwazulu-Natal, South Africa. Emails: kristen.lyons "at" uq.edu.au; p.westoby "at" uq.edu.au; nela "at" ukzn.ac.za. This is the sixth article in Connor Cavanagh and Tor Benjaminsen (eds.) 2017. "Political ecologies of the green economy", Special Section of the Journal of Political Ecology, 24: 200-341.
} 
programmes «de réforme» et «rebelles» ou «radicaux». Les stratégies dominantes visent à réformer les marchés du carbone et la gouvernance forestière associée. Entre-temps, un programme rebelle ou radical - y compris le rejet de la langue et de l'idéologie du commerce du carbone, ainsi que la construction de mouvements autonomes au niveau local soutenant les droits de l'homme - émergent dans les espaces restreints de la gouvernance économique verte privatisée et un État militarisé. Il existe des possibilités restreintes d'organiser des mouvements radicaux, et l'institutionnalisation fréquente et l'influence limitée des ONG. Mais la compréhension croissante de ces programmes radicaux de changement et de leurs contributions pour réinventer des modes de vie alternatifs est importante pour les chercheurs, les militants et les praticiens.

Mots clés: Marchés du carbone, REDD, Ouganda, alternatives de durabilité

\section{Resumen}

De manera global, los mercados de carbono han surgido como una característica central en las estrategias de mercado para hacer referencia a la crisis climática. El mercado global en carbono, tiene como premisa la posibilidad de reducir las emisiones globales de gas invernadero y estabilizar el clima terrestre, mientras que al mismo tiempo se generen nuevas formas de acumulación de capital. Entre las iniciativas de mercados de carbono se incluyen proyectos de Reducción de Emisiones de Deforestación y Degradación (REDD) los cuales conectan a campesinos y agricultores de subsistencia en el sur con consumidores e industrias del norte. En el continente africano, estos proyectos se están expandiendo y están provocando impactos sociales, económicos y ecológicos. En este artículo trazamos movimientos en respuesta a mercados de carbono. A través de un estudio de varias ONGs que tienen actividad en campañas relacionadas con mercados de carbono en Uganda, examinamos las estrategias y tácticas de los movimientos que surgen en respuesta a la creciente economía de carbono. Nuestros hallazgos demuestran que los acercamientos de las ONGs se mueven entre y a través de agendas de cambio radicales o de reforma y rebeldía. Las estrategias que dominan están dirigidas a la reforma de los mercados de carbono y de gobernanza forestal asociada. Mientras tanto, una agenda de cambio radical o rebelde - que incluye el rechazo al lenguaje y la ideología del comercio de carbono, a la par de construir movimientos locales autónomos basados en los derechos - surge en los constreñidos espacios de gobernanza económica verde privatizada y el estado militarizado. Dadas las constreñidas oportunidades para la organización de movimientos radicales, y la frecuente institucionalización y limitada influencia de las NGOs, el incremento en el entendimiento de estas agendas radicales de cambio y sus contribuciones para la re-imaginación de sustentabilidades alternativas, se vuelven relevantes para académicos, activistas y profesionistas por igual.

Palabras clave: Mercados de carbono, REDD, Uganda, sustentabilidades alternativas

\section{Introduction}

In his book To cook a continent (2012), Nigerian environmental activist Nnimmo Bassey poignantly documented the impacts of climate change on the African continent. Bassey, along with others (Bond 2013; O'Brien and Leichenko 2010), describes global warming as giving rise to a new order of social, ecological and economic impacts, and with an estimated cost of US\$36.6 billion per year (Health Poverty Action 2015). In parallel, the 'green economy' and associated green forms of governance have become a key foci of global responses to climate change, including as part of the now ratified United Nations Framework Convention on Climate Change (UNFCCC) 2015 Paris Agreement (Corson et al. 2015). Green economic processes are increasing pressure to convert forests, agricultural lands (and other landscapes) into alternative land uses related to so-called green economic activities; including biofuels, timber, pulp and paper, and agribusiness plantations (Nielsen 2016; Mwangi and Wardell 2012). In Uganda, between 2008 and 2010 alone, large-scale commercial land deals converted close to 15\% of agricultural land into Reduction of Emissions from Deforestation and Degradation (REDD) projects, carbon capture and forestry schemes, and other related initiatives (Martinello 2015). In so doing, these initiatives give rise to an array of equity and justice issues and challenges, especially for immediately affected Indigenous and local communities (Okereke and Dooley 2010). 
In this context, the objective of this article is to further understand the responses made by social movements to green economic activities. Building on calls from Borras and Franco (2013) and Hall et al. (2015) for greater analysis of 'the politics from below', our work contributes to the growing body of literature that examines how, and on what terms, movements are engaged in processes and politics related to the green economy. In so doing, our work examines the extent to which movements are reforming, resisting or reimagining the green economy, with outcomes that open up possibilities for alternative sustainabilities to flourish. To do this, our article charts local-level responses to carbon markets, one of a number of ecosystem services that has emerged in the context of the climate crisis. Amongst these carbon trade initiatives are an array of plantation forestry initiatives, such as Reducing Emissions from Deforestation and forest Degradation (REDD+), as well as the related Afforestation/Reforestation Clean Development Mechanism and Voluntary Carbon Market initiatives, which we refer to collectively as REDD type projects. ${ }^{2}$

Africa-based social movements have engaged with such initiatives since the early 2000s, alongside global movements and the formal inclusion of civil society in UN-related processes (Corson et al. 2015). In this article we examine engagement with, and responses to, plantation forestry/carbon market initiatives amongst a number of NGOs working at the local level, most of which also have international connections. Our country context is Uganda, widely recognized as one of the earliest African nations to participate in global carbon markets (Cavanagh and Benjaminsen 2014; Nel 2014). Our analysis focuses on the strategies of a sample of NGOs working specifically in the nexus of Ugandan climate change, social justice and equity. These include those engaged to reform the sector, as well as those seeking a more radical change agenda, including actively pursuing alternative visions for sustainability and local level development. Our selection of NGOs illustrates the spectrum of social movement responses. In addition to presenting findings based on a broad cross section of NGOs, we provide two case studies - Oxfam and their local partner the Uganda Land Alliance, and the National Association for Professional Environmentalists (NAPE). We do not provide a comprehensive overview of all NGOs engaged in movement-organizing and strategies related to carbon markets in Uganda.

We conclude that movement strategies are constantly imagined and reimagined in the context of national and international politics. The privatized green economy, market environmentalism, and governance taking place beyond the state are key in defining Uganda's social movements. For the most part, these movements navigate constrained spaces to reform the growing carbon market sector, thereby delivering some incremental wins, especially related to social justice. In a minority of cases, however, movement organizing is also re-imagining climate solutions via community organizing around alternative sustainabilities that transform understandings of justice and rights. The capacity of movements to articulate such a radical change agenda, and the positive outcomes this might enable for communities and ecologies at the local level, is all the more significant given the constraints that green governance mechanisms impose upon local level actors. This includes their reliance on top down and carbon-centred approaches, alongside Uganda's increasingly militarized State (Nielsen 2016).

The article begins with an overview of global carbon markets, the literature on Uganda, and the response from civil society. We then introduce the methodology and present our findings related to diverse movement strategies of NGOs, as well as the national policy and the legal and cultural settings in which movement-organizing occurs.

\section{Global carbon markets}

There are a growing number of initiatives aimed at climate change mitigation, with many linking investors and consumers from the global north with smallholder and peasant farmers in the global south. The premise of global carbon markets is that GHG emissions that occur in one part of the world can be offset by sequestration activities elsewhere (Lohmann 2011). Plantation forestry carbon market initiatives are one such type, and rely upon calculative practices that measure and price the volume of carbon dioxide

${ }^{2}$ See www.REDDmonitor.org 
and other greenhouse gases (GHG) sequestered (or absorbed) from the atmosphere into wood, leaves, soil and organic matter (Bumpus 2011; Miller 1992; Nel and Hill 2013). These calculative processes rely upon an assemblage of international carbon market and forestry governance actors and processes, that in turn intersect with local socio-cultural contexts (Descheneau and Peterson 2011; Nel 2014; 2015).

There is a growing literature that examines the burgeoning arena of carbon markets, including REDD+ and REDD type projects, especially since 2007, when the UNFCCC Conference of Parties agreed to adopt an international REDD mechanism (Mbatu 2016). Emerging themes have focused upon the ecological and social inputs that constitute the carbon economy, including scrutiny of the construction and application of metrics by which carbon is rendered knowable and translated into a tradable commodity. In terms of governance issues and challenges, the morality of global governance frameworks, as well as questions of participation, inclusion and co-option of civil society and other interests has been examined (Okereke and Dooley 2010; Suisseya and Caplow 2013; Schroeder and McDermott 2014).

Walbott (2014), for example, identified the success of Indigenous peoples as 'norm entrepreneurs' in climate negotiations, with outcomes that were able to shape the climate governance agenda. Meanwhile, Astuti and McGregor (2016) found REDD+ projects as fostering a particular kind of Indigenous subjectivity that excluded many affected community members, and rendering only those able to 'perform' as able to benefit from projects. Similarly, Kandel (2015) noted that even when improvements in global governance frameworks were achieved, the outcome was to privilege the inclusion of certain voices, meanwhile failing to address the needs of those most vulnerable, including those most affected by carbon market projects. Corson et al. (2015) also described civil society as being disciplined by governance processes in ways that sidelined radical views, with outcomes that legitimized the green economy as the status quo.

Literature has also emerged outlining local level impacts of the expanding carbon economy, including injustice related to land tenure and access rights, as well as local natural resource rights, with indigenous and local communities especially impacted (Lyons and Westoby 2014; Mbatu 2016; Okereke and Dooley 2010; Schroeder and McDermott 2014; Suisseya and Caplow 2013). Literature also identifies the erosion of biodiversity, the militarization of conservation and associated violence by the state (Benjaminsen and Bryceson 2012; Bottazzi et al. 2013; Büscher 2013; Cavanagh et al. 2015; Fairhead et al. 2012; German et al. 2014; Martinello 2015; White et al. 2012).

This literature points to the failing of carbon markets, including REDD and REDD-type projects in particular, as well as highlighting the urgent need to address the social (and ecological) justice gaps in global carbon market and forest governance. It is in this space our article sits, by scrutinizing the strategies of selected NGOs in responding to these failings. We now turn to the particularity of Ugandan carbon markets.

\section{Ugandan carbon markets}

Uganda was one of the first countries on the African continent to engage in carbon markets (Cavanagh and Benjaminsen 2014; Nel 2014). The first highly controversial project was established by the FACE Foundation, and in collaboration with the Ugandan Wildlife Authority (UWA), in 1994, and led to violent evictions, human rights abuses and land conflicts. Since then, the number of carbon market initiatives has expanded, with national and international NGOs (including WWF and the Jane Goodall Institute, amongst others) actively involved in establishing afforestation and reforestation, forest management, cropland and grazing land management projects. These are supported by international funding, including the World Bank carbon funds and the COMESA Carbon Fund, and with institutional support via the Uganda Carbon Bureau and the Forest Carbon Partnership Facilities' REDD Readiness Preparation (RPP) process. In fact, today Uganda is the origin of the fourth largest market share of carbon forestry credits (Peters-Stanley et al. 2012).

The Ugandan Government is committed to expanding national capacity and participation in global carbon markets. For example, the Uganda Investment Authority was established to promote national economic growth via international investor participation, including investment in carbon initiatives, such as 
forestry for timber and carbon offsetting. In recent years, too, Uganda began readying itself for participation in the REDD+ market. These processes have also intersected with the neoliberalization of forestry governance in the country (Nel 2015). In particular, the country's exclusionary "fortress conservation model" (Brockington 2002) pertaining to protected forest areas was re-enforced through the National Forestry and Tree Planting Act (2003), formulated to a significant extent by the director of the Uganda Carbon Bureau (UCB). This Act continues to paint those dwelling on Central Forest Reserves as 'encroachers', even though this portrayal is acknowledged to be problematic, including by CARE and the Advocate's Coalition for Development and the Environment (ACODE), and academics (Cavanagh and Benjaminsen 2014). Despite such concerns, the ongoing operationalizing of this approach is driving conservation enclosures and land appropriations by national and local actors (Cavanagh et al. 2015; Kandel 2015), conditions that are matched with frequent political repression by the state to silence contestation and opposition (Martinello 2015). There are multiple responses to this, however, which we now consider.

\section{Diverse movement responses to carbon markets}

Civil society, including environmental movements, have been engaged as key actors in shaping policy and policy making processes over the long term (Dryzek et al. 2003). Since at least the 1980s, and coinciding with a broader deliberative turn, or 'governance-beyond-the-state' (Swyngedouw 2005), Dryzek (1997) describes the normalization of a 'reform environmentalism'; referring to the centralization of pluralist processes of decision making that rely upon dialogue with a diversity of perspectives, including 'movement organizations.' This democratic pragmatism is demonstrated in growing NGO engagement in what Moyer et al. (1991) has described as reform tactics for social change - including community participation, consultation and engagement activities. While early forms of NGO engagement in environmental decision-making were about politics and governance, they are increasingly including engagement in economic decision-making (Boehnert 2015). This ecologically modernist shift (Mol 2000) positions NGOs as key actors in deliberative processes that are market-based. The green economy, legitimized by the Rio+20 United Nations Environment Program in its Towards a green economy: pathways to sustainable development and poverty eradication (2011), and with a specific participatory process for civil society inclusion (Corson et al. 2015), is one approach to the privatization of environmental management and the integration of NGOs into an economy of environmental governance. Yet stakeholder-based approaches can be ad hoc and often informal, and as such are often riddled with problems, including their degree of democratic content, as well as the contradictory tensions and uneven power relationships embedded within them (Dryzek 2000; Swyngedouw 2005).

At the same time that reform-based NGOs have formalized their dealings with the state, other movements have been engaged in a broader range of struggles against public and private sector interests, with diverse strategies and tactics (Martinello 2015). Kandel (2015) has described them as covert and overt, with everyday forms of resistance and opposition to the dominant pathways of development. In many instances, the latter are geared towards the destruction of peasant farming and Indigenous peoples' existence. In response, struggles and movements call for recognition for rights, including autonomy and sovereignty over land and natural assets (Martinello 2015). Following in the tradition of these scholars, in our research we have been interested in the kinds of strategies NGOs have engaged that demonstrate 'rebel' roles (Moyer et al. 2001), including activities that create tensions; by challenging assumptions, norms, processes and outcomes, and often articulating radical alternative visions for solutions to the climate crisis.

NGOs engaged in carbon market and related forestry movements and campaigns (including in Uganda) demonstrate diverse strategies that cross the spectrum of 'reform' and 'rebel' roles. Many NGOs (including large international NGOs), for example, have engaged in national and international policy framework dialogues as core components of their campaign strategies. Participation in dialogues at the United Nations Conference of Parties (COP), REDD negotiations and the Climate Community and Biodiversity Alliance (CCBA) standards negotiations, for example, have delivered incremental emissions reductions, reforms in governance processes and revisions to standards. 
Yet these kinds of reform processes have been strongly critiqued, with Bracking (2015) arguing NGOs' few precious resources and energy are drawn into processes that will achieve small gains (at best), while at the same time limiting other framing of the issues, and constraining engagement in other strategies. This was observed at a Civil Society Organization (CSO) Input meeting with Uganda's National Environmental Management Authority (NEMA) negotiators for the UNFCCC's Congress of the Parties (COP) 18 in 2012. The CSOs inputs were often highly critical of internal failures of Ugandan environmental management, and felt their voices were not recognized. As one of the delegates at the meeting commented "whenever CSOs invite government to harmonize positions, the negotiators are there in the morning and in the afternoon they leave; and this is when we try to harmonize... Are we harmonizing or just toeing a divergent line?" Reflecting these concerns, some NGOs have either refused to participate, or later walked away from such processes, rather than legitimize a "deeply flawed system of climate finance and its anti politics" (Bracking 2015: 298). At the 2002 World Summit on Sustainable Development in South Africa, for example, an estimated 30,000 people marched out in protest, describing consultative processes as failing to allow activists to discuss the most substantive issues, including compensation for developing countries for impacts of climate change (Mennie 2013). NGOs continue to 'walk out', including leaving the climate talks in Copenhagen in 2009 and Paris in 2015 (Bond 2011). The No REDD in Africa movement, in particular, highlights the risks of REDD+ projects and large-scale bioenergy production schemes for communities; including involuntary displacements of communities and other forms of so-called 'green land grabbing' (Bassey 2013).

Having considered the contexts that orient this article, we now overview our methodology and present key findings and analysis.

\section{Methodology}

The objective of our research was to understand the responses of movements to carbon markets in Uganda, including specific responses to REDD-type projects. Building on prior literature, and the current limits in understandings of the 'politics from below', our methodology was designed to elicit understandings of the diversity of movement strategies, including 'reform' and 'rebel.' Given the dominance of reform approaches, for reasons introduced earlier, we adopted a non-random and snowball sampling approach to ensure that NGOs with diverse approaches were included in the study.

The empirical data we present draws from interviews with activists from NGOs engaged in carbon market and related justice and equity campaigns. Interview questions were open ended, enabling participants to talk broadly about relevant campaigns they were involved in, their organizations' change agenda, relationships with other NGOs, and related topics. Interviews were undertaken with nine activists from six selected NGOs in Uganda in 2014. On the basis of NGOs' alliances with other groups, the NGOs included in this study are connected to hundreds of organizations, mostly local and national. Furthermore, an extensive series of interviews with actors in the forestry governance sphere, including NGOs, was undertaking during the PhD fieldwork of the third author in 2012 (Nel 2014).

Participant observation was also undertaken at various events that brought together NGOs, government and industry actors, including the National Association of Professional Environmentalists (NAPE) Friends of the Earth workshop (by Lyons and Westoby) that brought together campaigners across the African continent; the national REDD Steering committee meetings; a meeting on regional safeguards and participation in REDD-type projects in Nairobi; and, a meeting between government and Ugandan NGOs to harmonise a negotiating position ahead of the 2012 COP (facilitated by the Bwaise facility for climate change) (by Nel). In addition, primary data was supplemented with analysis of a range of NGO strategy documents, annual reports and other related material.

In order to provide a detailed and comparative analysis of 'reform' and 'rebel' movement approaches, we also selected two NGOs as case studies as part of our analysis. Firstly Oxfam, and its local partner the Ugandan Land Alliance, and secondly the National Association of Professional Environmentalists (NAPE), a Friends of the Earth International Affiliate Group. In each of these cases, we conducted a series of repeat interviews, as well as in-depth analysis of organization documents. 
There are a number of ethical issues for consideration in the conduct of this research. In particular, a number of activists with whom we spoke described the challenging political context in which Ugandan NGOs operated, with amplified controls by the state. In this context, it is sometimes difficult for activists to speak openly about their organizations' activities. Given this, data is presented so as to ensure the anonymity of participants. The research was approved by The University of Queensland Ethics Committee.

\section{Mapping NGO Strategies}

We start here by mapping the diversity of activities NGOs are engaged in related to carbon market campaigning in Uganda. Our findings demonstrate a diversity of NGO strategies that resonate with reform and rebel approaches. While the activities of NGOs enable us, on the one hand, to differentiate between these approaches, our analysis also highlights the convergence and tensions between them in the context of broader NGO alliance building, climate politics, as well as national and international policy settings. We report on our two case studies - Oxfam/ULA and the National Association of Professional Environmentalists (NAPE) - to demonstrate some of these tensions and convergences.

\section{A reform change agenda}

Amongst the NGOs included in our study, the dominant approach for affecting change within carbon markets relied upon direct engagement in activities with government, the private sector and community organizations. At the heart of this approach was the desire to "be at the table", a position many activists described as enabling them to affect governance and decision-making processes, as well as their outcomes. For example, activists described their NGOs' participation in processes related to state-based policy setting and private codes of conduct in the fields of carbon markets, as well as land use decisionmaking. This included being active participants in government led dialogues as well as other initiatives related to the formation of a national climate change policy, REDD Readiness, as well as engaging in legal and court proceedings. A number of activists described these activities as part of their 'insider' approach to affecting change, including differentiating their approach to that of organizations who work from the 'outside' (a theme we return to below).

In explaining their organizations 'insider' tactics, a number of activists described working in collaboration with government and industry as an opportunity to gain access to decision making processes. One activist from the Ugandan Coalition for Sustainable Development (UCSD), who spearheaded an influential DfID ${ }^{3}$ funded, and Ugandan focused REDD information dissemination and participation platform entitled REDDnet, explained: "To influence policy, we think it is more effective to work from inside ... because you are able to (make) change at that table." He later affirmed, "If you want to see change, being inside is where and when it is possible." Reflecting this, one activist from the UCSD described his organization as having invested considerable time and resources in activities to develop Uganda's REDD Readiness program, with outcomes he described as ensuring REDD Uganda was driven by a pro-poor agenda. He understood UCSD's involvement as key in ensuring this outcome. Similarly, activists from the Climate Action Network Uganda (CANU) described their organization's approach as "choosing to be inside." These activists understood their engagement with the national government over a number of years had delivered some tangible results, including drawing national political attention to climate change, as well as enabling them to - in one activists' words - "shape climate change related policies."

A number of activists also described collaboration with government and private sector actors as lending legitimacy to policymaking and the Ugandan carbon market. Some activists described their participation as ensuring "good governance" - something on which the national government depended, a position that granted them bargaining power with government and other private sector actors. CANU, for example, described their network as having successfully raised the issues and concerns of local communities in climate change policy negotiations. While some activists articulated support for market

\footnotetext{
${ }^{3}$ Department for International Development, British overseas aid.
} 
based approaches to development - including integrating smallholder farmers into international carbon markets - they also described the importance of ensuring any hardships endured by local people as a consequence of development were compensated (interview with PELUM ${ }^{4}$ ).

At the same time, activists also described their participation in national level climate governance processes as lending legitimacy to broader issues to which their organization held concerns. For example, while CANU activists described support for 'green economy' forms of development in general, their organization often championed green development strategies that differed from those of the government or private sector actors, who they saw as frequently championing development interventions that had "the wrong foundations." One activist explained that the priority of development should first and foremost ensure immediate social and economic needs, leaving carbon trading (and other "additionalities") for consideration only after vital needs are realized. Specifically, activists raised concerns about the negative environmental impacts of industrial plantation forestry for carbon markets, describing its reliance on exotic species and monoculture plantations. They also pointed to the hypocrisy of land clearing to establish monocultures for carbon offsetting, the adverse impacts of industrial forestry management regimes including habitat loss and chemical pollution - as well as the efficacy of carbon sequestration in monoculture pine plantations. One activist from CANU explained:

It is very difficult to see a plantation company not using exotic species. But we don't see these pine trees as being very effective. They don't have a large surface leaf area. We have had a debate here about how effective pines can be in sequestering carbon, given the little surface area of leaves.

In addition to this concern, the introduction of exotic species in monoculture plantations was also associated with the loss of native forest cover, savannah and grassland, something that carbon governance failed to account for.

Overall, while the majority of activists with whom we spoke described engaging in reform activities of different types, they also described various constraints upon their ability to negotiate and dialog with government and private sector actors, and frustrations about the outcomes. Yet despite these constraints, NGOs described reform tactics as a necessary and pragmatic approach in the context of broader national policies that exert pressures on NGOs (a theme we return to below). By working 'inside', many activists saw their NGO as able to achieve incremental changes that could deliver some benefits at the local level.

\section{Oxfam/Uganda Land Alliance and its reformer roles}

We now examine some of the strategies of the first of our selected case studies, Oxfam, and its local partner the Uganda Land Alliance. The focus is particularly on their activities related to industrial plantation operator the New Forests Company, part-funded by a speculative agricultural fund Agri-Vie, HSBC bank, and the International Finance Corporation (IFC) of the World Bank (see Grainger and Geary 2011). Our purpose is to explore some of the tensions, and outcomes, arising from this reform approach. While Oxfam and ULA's advocacy around this company's activities might initially have been seen as radical - in directly challenging evictions perpetuated by government actors - the mediation they entered into led to a shift to a reformist agenda.

The Ugandan forestry sector is familiar with controversy. When it occurs, the Uganda Wildlife Authority (UWA) and the National Forestry Authority (NFA) approach it with some trepidation. These tensions were laid bare in 2011 by an explosive and widely publicised Oxfam report which elicited an international outcry over the alleged eviction, between 2009 and 2011, of 22,500 'encroachers' from the New Forests Company's (NFC) two Central Forest Reserves leased from the National Forestry Authority (NFA) in Kiboga District of Western Uganda. While there is no hard data on these figures, interview

\footnotetext{
${ }^{4}$ Participatory Ecological Land Use Management Association, Uganda - part of a regional network of over 220 civil society organizations in twelve countries in East, Central and Southern Africa.
} 
responses speculate the number was more likely 15,000. The evictions were effected between 2009 and 2011 with the aid of the police and the army, to make way for forestry plantations, one of which was doubling as a Clean Development Mechanism project. Furthermore, this cycle of encroachment and eviction was not a once-off, isolated incident, but iterative and persistent. According to an NFA official the evictions between 2009 and 2011 at Luwunga, for instance, followed others that took place in 1988 and 1996 (NFA Official, Interview, September 2012), which at the very least shows that the territoriality of the CFRs in questions is disputed and contested.

The Oxfam report (Grainger and Geary 2011) was intended to form a core 'win' on 'land grabs' for its nascent GROW: Food. Life. Planet campaign (Interview, Oxfam Representative, Auckland, New Zealand, Dec 2012), and to give a voice to communities who "lack the power to claim their rights effectively, and to defend and advance their interests" (GROW campaign website). The report levelled its critique against the New Forests Company, and lodged a complaint against both the Forest Stewardship Council (FSC) and the Ombusdman of the International Finance Corporation of the World Bank, which was a shareholder of the project.

The report contested the fairness of the evictions and the labelling of the evictees as foreign, Rwandan encroachers (New Forests Company 2011) by the NFA and NFC. It cited evictee's testimonies as to losses of what they regarded as 'their land' - to which many claimed lawful entitlement, some for over 40 years - and loss of their livelihoods after evictions (Institute for Security Studies 2011). Oxfam's call for transparency and fairness was certainly justified, according to a Human Rights Network's (HURINET) officer who observed the evictions; "there were so many army and police, and the biggest problem was not involving the communities, they just gave notice then beat and chased them. They nearly arrested some people from Hurinet, and some New Forest officers were very, very arrogant" (Interview, Kampala August 2012).

In describing the Ugandan government and the company's activities, an academic from Makerere University put it; "the laws might be very favourable for you here, but not necessarily favourable at the international level; and that's where the NFA and New Forests made mistakes" (Interview, Makerere Dept. of Forestry and Nature Conservation, June 2012). For a time this international uproar undermined shareholder confidence in the UK based company. Yet the contestation was quickly contained, at least for a period, through the government backing the New Forests Company and threatening to silence dissenting voices by evicting Oxfam from the country, and removing the ULA's license, thereby effectively curtailing its advocacy work.

In the context of these threats, Oxfam/ULA were engaged as representatives for, and advisors to, affected communities (at their request) as part of their mediation with the company. After a long and drawn out process, a settlement was brokered by the International Finance Corporation (IFC) of the World Bank (a part-financier of the project) in which affected communities from the Namwasa CFR were to receive compensation. The settlement, however, was limited to supporting unspecified 'community development projects' and the residents have not been allowed to return to their land, while a second settlement for the Luwunga CFR is still pending. Importantly for our analysis, Oxfam did not challenge the Government's actions (or highlight political connections to the project) or carbon forestry itself, as its earlier report Turning carbon into gold indicates (Oxfam America 2008). Rather, it appeared to direct its strategy towards ensuring positive outcomes for locally affected communities - as defined by communities themselves - through the mediation process. While details of this high profile mediation case are embargoed pending the outcomes of the Luwunga CFR mediation, there are a number of observations that can be made.

To begin, it appears that the kind of advocacy and rights-based claims deployed by Oxfam were constrained by the broader political economy and ecology within which the evictions were located, including: 
- Restrictive NGO legislation ${ }^{5}$;

- A broader de-territorialization - the weakening of protected area boundaries over time alongside increasing 'encroachment', often facilitated by corrupt officials;

- The proactive role of patronage - political support for the evictions which have otherwise been banned in the country following a Presidential order in 2006.

This political support was secured after NFC and Uganda Tree Growers Association (UTGA) representatives met with the President at the Presidential Round Table on Investment in 2009. Two respondents in the forestry sector went so far as to offer conjecture that a family member of the President was connected to the company (Interviews, Kampala, November 2009), but what is evident is political support enabled evictions by the hand of the army and police. Furthermore, despite claims of noninterference in a NFA and government matter, the NFC is alleged to have facilitated the co-ordination of evictions themselves; "we told them [the NFC] was what was needed there, drew a budget, and they facilitated us... Because if we had to wait for the money of government (laughs) it was very difficult" (Interview, NFA Official, October 2012). Finally there was a conflict of interest concerning the arbitrator of one facet of the case. The FSC appointed SGS; whose employer was the World Bank and the New Forests Company. With these factors at play, scope for the advancement of community interests through the arbitration of the IFC ombudsman and the FSC auditor, though laudable, could be seen as severely curtailed.

To be fair to the New Forests Company, they are likely to have tried to be more accommodating to the encroachers who were evicted, but they were told it was a government responsibility (Interview, Uganda Carbon Bureau representative, Interview June 2012). Oxfam, for their part, were hesitant to implicate the government to avoid initial adversarial relations in their ongoing relationship, and did not substantively engage forestry staff in their investigations. At the same time, Oxfam's strategic approach can also be seen as having been informed by its organizational politics, including a commitment to support local communities, including in their decision to form cooperatives and negotiate with the New Forests Company. This apparent tension between Oxfam's approach to change and commitment to grassroots approaches to development then, appears to have played a significant part in driving its strategies, including in particular its key role in the mediation processes at the centre of this controversy.

In contrast, the Uganda Land Alliance engaged with the issue as part of their broader work on contestations over land, and would potentially have been more critical in their stance but for their partnership with Oxfam, which has been criticised in the past for its potential to curtail ULA's ideological, organizational and financial autonomy (Bazaara 2000). In any event it is evident that the scale of the international response, as well as the government's reactionary stance, took Oxfam and ULA by surprise.

\section{A radical change agenda}

In contrast to the approach of Oxfam/Uganda Land Alliance, and other NGOs' as outlined above, a few NGOs included in our research opted to work 'outside' formal processes, including engaging in strategies that enabled them to influence change in ways resonant with a 'rebel', or radical, tradition (Moyer et al. 2001).

For these activists, reform approaches were seen as time and resource intensive, and often ineffective in delivering positive outcomes, especially around climate justice and the broad array of equity issues on which they campaigned. The National Association for Professional Environmentalists (NAPE), a Friends of the Earth International (FoE I) affiliate group, for example, described the market-based approach underpinning climate negotiations, including REDD Readiness, as untenable in terms of delivering environmental and social just outcomes. Demonstrating a rejection of market based strategies to address the

5 This is not to argue that rights based approaches are without their utility. In other carbon forestry projects and at national level there have been acknowledgements of the need for processes of community consultation and Free and Prior Informed Consent (FPIC) and more 'participatory' processes when handling such issues. 
climate crisis, both NAPE and FOE I articulate a staunch anti-REDD position. They sit with a growing number of international organizations who critique corporate controlled market environmentalism and the financialization of nature (eg. see www.REDDmonitor.org). As one activist explained, if we are not "disrupting the neoliberal project", we are "not doing the work." Both NAPE and FOE I also described reform approaches - such as participating in COP and REDD Readiness - as inconsistent with their environmental and social justice agenda that places humans and ecological rights at the centre of understandings of 'the development project', not markets. Similarly, HURINET-U (The Human Rights Network Uganda), described market-based approaches such as carbon markets as inconsistent with their human rights agenda.

Ugandan activists engaged in rebel-type activities expressed frustrations with negotiations that played out in the Rio Earth Summit and Rio +20 events. One activist described these as "amounting to nothing", and lamented "the environment has been further degraded since the Rio Earth Summit in 1992 ... (with) government, companies and financial investors not held to account." Pointing to the failure of these processes to deliver meaningful environmental outcomes, another declared the best that could be hoped from attendance at the Rio +20 was a new t-shirt.

With both international and national formal processes frequently described as incapable of delivering on the environmental and social justice agendas of NGOs, a small number of Ugandan NGOs described the adoption of 'rebel' strategies as vital to achieve positive changes. These activists described investing organizational capacity - with the limited financial resources they had available - into approaches they believed could deliver the most effective results. For NAPE, this included exposing the structural causes and impacts of what they described as the 'financialization of nature', including erosion of biodiversity and loss of access and rights to natural assets amongst Indigenous and peasant farmer communities. It also included building grassroots community capacity, including creating and strengthening alliances across movements regionally, nationally and internationally through its community education strategy for social change, to engender locally driven activities focused on autonomy and sovereignty.

\section{NAPE's rebel strategy}

NAPE was one of few NGOs with whom we spoke with engaged in what can be construed as a rebel, or radical, strategy for change.

As stated above, a central component of NAPE campaigning includes community based popular education, including supporting communities to better understand their rights - particularly in the context of expanding extractive industries - as well as a focus upon a critique of market based strategies around climate change. In particular, NAPE have constantly opposed REDD and REDD+ initiatives. This oppositional stance has created tensions with other NGOs, however NAPE have successfully balanced these tensions, enabling them to maintain strategic alliances with other NGOs who do not necessarily share their strategic approach.

Whilst holding a radical agenda, NAPE has also shifted their strategies and tactics for social change over time. Theorizing their social change approach through substantive reflection and experimentation, they have moved from earlier engagement with legal appproaches, towards community mobilizationorganizing and building a social movement. Interviews illuminated how a key catalyst for this shift was their experience in the Mabira Forest Campaign, a significant historical event in the environmental movement in Uganda (Twesigye 2008). While previous organizational strategies to oppose inappropriate investment, or land grabbing had frequently focused on legal challenges, NAPE staff reflected on the failure of court challenges to deliver fair outcomes. They also described the success of community mobilization around the Mabira Forest campaign. As a result, this led NAPE to shift its campaign approach. As one of the NAPE staff put it: 
We changed our strategy because of a big issue. This was the Mabira Forest conflict - where the government wanted to give a third of it (the forest) to investors to grow sugar cane. And the people said no 'we don't want sugar, we want our forest'. And a big war started - some people went to prison, and there was a court case and we won. Prior to this we believed in court cases/legal battles, and we had many battles, and we're still in court after 3, 5, 7, even 10 years. (But) we've changed strategy to be more community-led, building a movement. We've learned that, the best court is the power of the people. As part of the Mabira campaign we worked directly with communities. We still work at a national and international level as we did, engaging government is important, but it is really important to engage people with this community-led approach too.

This community-led approach, focused on community mobilizing and building the movement, has been operationalized through a particular methodology called 'Sustainability Schools', or 'Sustainability Villages' (see Westoby and Lyons, forthcoming). Sustainability Schools are based upon a popular education approach, whereby NAPE work with communities on the edges of, or within, resource conflict zones, to ensure they have enough information to support them in informed negotiation with companies and government, as well as the confidence and networks to ensure free and prior informed consent about their future. At the heart of the program is equipping local community members with the knowledge to understand and assert their rights in the context of negotiations with both the state and private sector interests. One activist briefly explained this approach as:

Draw [ing] on Freire's work in our training/education. We also focus on unlearning. We want knowledge to sink into people's body and into their heart's, we don't emphasis writing. We use a community-led participatory action research approach too - They determine what they want. We then work with communities and take these (ideas) to district officials, traditional leaders, government etc. ... We also facilitate exchange programs between these sustainability villages, so they are learning from one another it's not 'top-down' from us, but from each other.

This reflection on the community-education approach provides insights into elements of NAPE's praxis. In particular, it demonstrates NAPE's commitment to dialogic learning, with outcomes that enable communities themselves to define local challenges, as well as charting local level responses. The Sustainability School model can also be understood as adopting a participatory action approach, including through 'horizontal learning processes' - or community exchange processes - whereby communities drive local knowledge co-production. The establishment of a local community Green Radio, and strongly supported by NAPE, has provided an important platform for local community members to share ideas and experiences, thereby building collective understandings and responses.

Through these deliberate processes of alliance building, the Sustainability School model is increasing local level capacities and bargaining power in relation to the authorities, including on issues related to land and natural assets. As an outcome, in the Hoima district for example, some local communities are rejecting a push for oil extraction by the state, and instead establishing a range of local level projects (including bee keeping and native tree planting) as part of re-imagining their future outside the constrained extractivist economy the state is attempting to secure. The Sustainability School program, and the local level community projects emerging as a consequence of the program, can be understood as radical initiatives that reject state based development, and instead chart alternative visions for local level sustainability.

Furthermore, through listening to local community-level analyse of future visions for their future, NAPE are able to take confidently more rebel and radical stances in national and international forums. The local-national-international articulations of learning, experiences and positions ensure congruency within the 'politics from below'. 


\section{Legislative and policy contexts shape movement responses}

Activists frequently described their chosen strategies and accompanying roles as negotiated within the context of broader legislative and policy forces that exist across scales. Such contexts appear to both open up, and close down, advocacy approaches. It is to these contexts we now turn.

To begin, activists frequently described an intersection of interest groups, with frequent reference to the conversion and/or collusion of government and private sector actor interests, including in the forestry sector. For example, one activist described the situation where government representatives were also financial beneficiaries of the forestry industry, including as shareholders of corporations (as alleged in the case of New Forests Company). The state or state functionaries were also widely recognized as being involved in perpetuating illegalities and informalities - for example facilitating evictions, despite an ostensible Presidential ban. As financial beneficiaries of forestry-related carbon market activities, the state invested - including via various forms of legal and other forms of influence and intimidation - in order to constrain civil society that opposed carbon markets.

Activists explained a number of these government interventions imposed at national and regional scales to constrain and/or silence civil society's dissenting voices. The intervention most widely referred to was the NGO Registration (Amendment) Act, which was described by one activist as leading to a "difficult climate for activism." This Act, including recent amendments, was widely understood as imposing restrictions on the operations of NGOs, including increased monitoring of their activities. The introduction of a periodic permit to operate, for example, was described by a number of activists as enabling government (through the Ministry for Internal Affairs) to intimidate NGOs; including threats a permit would be withheld from NGOs engaged in "inappropriate" activities. Oxfam and the Uganda Land Alliance both faced threats of deregistration under this Act. Meanwhile an activist from another NGO described "vocal NGOs being targeted and threatened with de-registration." This activist lamented: "the government doesn't want us to work politically", and as harnessing both policy and legal processes to constrain democratic dialogue. Another activist described phone tapping as a legal strategy of government to monitor NGO activities. Similarly, the Public Order Management Law was described by a number of activists as enforced "arbitrarily, to threaten, intimidate and thereby constrain some NGOs." A number of respondents described this law as infringing upon rights to assemble and to free speech.

Ugandan activists described the importance of working within these (and other) national legal frameworks, or running the risk of being labelled an "economic saboteur." This was a theme reiterated by activists from elsewhere on the African continent who attended workshops we observed; who described sanctions and bans for organizations charged as saboteurs. This was a message that came from the top in Uganda, with recent and repeated Presidential addresses by Museveni describing activists who opposed international investment as "enemies of the state."

The decision to adopt insider strategies, then, represents a deliberate choice for activists seeking to avoid intense government scrutiny, intimidation and more. Indeed, and in this context, one activist described insider strategies for change as being most viable given they included activities "the government does not feel", and therefore would not seek to close down. Insider strategies represent, for at least some NGOs, a subversive approach for exerting pressure upon government and the private sector, within the spaces that remain open to activist organizations. Even NAPE, who described a rebel, or radical change strategy, appeared to mediate their Sustainability School model for community organizing within the context of this political landscape. For example, activists from NAPE described the loose structure of Sustainability Schools - with no principal, formal students or school buildings - as enabling them to evade the scrutiny of government. One activist described the government as threatening their organization, including some government staff claiming "we are going to close down your schools, as your organization is operating without the correct license." Yet he comically explained, "they couldn't find a school, which confused them", given the Sustainability School model does not rely on physical infrastructure to exist.

Further evidence of this joint opening up and closing down of NGOs' opportunities to affect change was reflected in Oxfam/ULAs' entry into mediation mechanisms through the ombudsman of the IFC to 
which Oxfam/ULA was engaged. This process enabled the NGOs room for advocacy, though by their own admissions, they were 'contained' by such processes.

Finally, securing on-going funding for advocacy work also appeared tied to activists' commitment to reformer, or insider strategies. Demonstrating this, the Climate and Development Initiative (CDI) - authors of the original critical report on Mt Elgon, with Chris Lang - appeared to struggle for funding as a result of their radical stance. The CDI appears to have a diametrically opposed position to UCSD and other reformer NGOs, and have been described by UCSD as so radical as to make them irrelevant. The International Union for the Conservation of Nature (IUCN) also described 'reformer' approaches as central to ensuring on-going funding for working in the carbon forestry space. Demonstrative of this, working as an insider it was able to secure funding to formulate the countries' REDD consultation and participation plan as part of Uganda's REDD Readiness. However, IUCN conservation practitioners in Uganda lamented the loss of the organizations' influence during the inception of the Convention for Biological Diversity (CBD), and some from the Union expressed uneasiness with carbon forestry as an intervention.

\section{Discussion - activist roles: navigating the tensions}

In this article we have sought to map the diverse strategies related to carbon market-related activism and movement organizing in Uganda. Our results point to a range of activist roles that move across 'reform' and 'rebel', or radical, agendas for change. Earlier theorizing of social movements (see Moyer 1991, and later Han 2014; Whelan and Lyons 2005) has mapped the diversity of activist roles as connected to diverse organizational theories of change; based upon incremental and disruptive strategies, respectively. Adding to this literature, our findings demonstrate the dominance of reform strategies amongst activist organizations in Uganda, and the significance of national and international policies in shaping the adoption of reform approaches. Our findings show activists navigate multi-scalar realities and relations, or governance beyond the state, in deciding upon their organizational strategies, with the politics of carbon markets and state agendas in opening up, and closing down, opportunities for NGO resistance and advocacy work.

NGO strategic approaches reported here also illuminate the agility within organizations that enables them to respond to shifting political contexts, whilst also attending to their own visions and strategic imperatives. Indeed, and as the cases of both Oxfam/ULA and NAPE demonstrate, NGOs shift strategies in the context of negotiating politics, as well as in the context of broader factors, such as the intended targets for critique and the identification of intended beneficiaries for advocacy work. For each of these NGOs, our findings show that activists' choice of target for critique (national government, private sector, carbon governance mechanisms), intended beneficiaries (local communities) and issue-base (climate justice, land grabs) are crucially important in assisting NGOs to navigate this terrain. In the case of Oxfam in particular, their targeting of the New Forests Company's Forest Stewardship Council certification, as well as the ombudsman of the IFC (instead of the state), and their decision to support the 'community' (homogeneously defined) appeared to shape their reform approach.

Our findings, and backed by previous research (see for example Gingembre 2015) also demonstrate the importance of alliance building - including transnational alliance building - in the context of carbon market advocacy and building movements. All of the NGOs with whom we spoke are building alliances with many other NGOs; creating webs of connections across national and international settings. Within these networks, NGO collectives can be seen as engaged in a diversity of strategies, connecting reform and rebel/radical approaches, thereby creating interconnected hubs that resonate with diverse activist roles, and with collective outcomes that expand NGO bargaining power. Activists themselves did not see these diverse approaches they engaged as being oppositional. Rather, they appeared able to reconcile - or at least hold - the tensions underpinning diverse approaches based on these broader alliances and collective movement goals. For example, activists described retaining their right to "speak out" (including NAPE's rebel role) against particular forms of carbon market development as part of their advocacy work, while at the same time respecting community decisions to negotiate, including work with a company or foreign investor so as to secure positive outcomes at the local community level. This ability to hold the tensions in 
the context of multi-scale complexities appears to us as a defining feature of the alliance of movements campaigning on carbon market issues in Uganda.

Yet our findings also point to some of the tensions between approaches and goals of NGOs and local communities, findings matched by other researchers (see Kandel 2015). In some circumstances, for example, we observed NGO organizational theories of change as sitting in direct tension with communities' aspirations and wishes. In these contexts, NGOs appeared committed to prioritizing local and indigenous knowledge to assist in resolving such tensions. For example, activists with whom we spoke emphasized the importance of local knowledge in adaptation to climate change - including tree planting and utilizing appropriate energy sources - and explained the significance of respecting local and indigenous knowledge. Yet whether such tensions will be managed into the future is yet to be seen, especially as the pressure from state and private sector interests continues to mount. Potential conflicts are also foreseeable between the beneficiaries of the Oxfam IFC mediation and those other community members excluded from compensatory development projects.

Related to this, rebel strategies also face on-going pressures from the state and private sector interests who are committed to expanding carbon markets and the green economy in Uganda. In this context, the future for NGOs working in this space can be expected to continue to face contestation. Yet it is rebel, or radical approaches, including those articulated in this article, that provide a little-heard critique of REDD type projects that are part of the market-based approach to the climate crisis. These approaches, including NAPE's Sustainability School model, provide alternative sustainability visions - one based on a critique of carbon markets from the local level. This movement is centralizing rights and justice in solutions to the climate crisis; a position articulated by United Nations Declarations (including Rights of Indigenous Peoples, and The Right to Development), including the 'right to say no' to carbon market initiatives, including REDD-type projects. Given the current limits to NGOs in pursuing this rebel, or radical agenda, the challenge remains to open up spaces for building such movements. The role of international alliancebuilding, as articulated by all NGOs included in our study, appears vital in this regard.

\section{Conclusions}

Carbon markets, including REDD type projects, are expanding rapidly on the African continent, and are associated with an array of social and ecological impacts. In response, diverse civil society-led movements have emerged, and deploying a range of 'reform' and 'rebel', or radical strategies to affect positive change at the local level.

'Governance beyond the state' - part and parcel of contemporary market environmentalism - is creating a complex multi scalar carbon market to which many NGOs are engaged in strategies to reform the sector. In this context, NGOs role is vital in ensuring some legacy of democratic decision-making into a space that is constrained by policy and political trends that favour private-led investment over community interests. In the context of the privatized carbon markets and the subsequent governance beyond the state inherent in market environmentalism, Uganda's NGOs are faced with the challenge of navigating the constrained spaces for affecting change, with considerable advocacy efforts directed towards reforming global carbon markets.

At the same time, a minority of NGO activities can be seen as embodying a rebel or radical agenda that is re-imagining alternative responses to the climate crisis, and articulating alternative visions of sustainability. At the heart of these is a justice agenda, articulating the rights and equity issues and impacts associated with global carbon markets. This is not new, with rebel activist roles playing a historically significant part in affecting positive environmental and social outcomes in Uganda (and elsewhere) including the landmark Mabira Forest case. NAPEs Sustainability School model is demonstrative of this radical agenda, including by re-visioning development from the ground up; with a rights based agenda enabling local communities to actively shape local development interventions, as well as understanding and acting in defence of their rights in the context of pressures from the state and private sector interests. Given these rebel/radical approaches are not simply surviving, but thriving in the context of broader structural forces at work to constrain and/or destroy them, their activities are all the more significant, for the local 
level benefits they deliver, and for the radical alternative pathway for positive social change they engender. Given this significance, the challenge remains to ensure local, national and international alliance-building can ensure the on-going effectiveness and flourishing of reform and radical movements into the future. This will be vital to open up future alternative sustainabilities that are yet to be realised.

\section{References}

Astuti, R. and McGregor, A. 2016. Indigenous land claims or green grabs: inclusions and exclusions within forest carbon politics in Indonesia. The Journal of Peasant Studies http://dx.doi.org/10.1080/03066150.2016.1197908

Bassey, N. 2012. To cook a continent: destructive extraction and the climate crisis in Africa. Cape Town: Pambazuka Press.

Bassey, N. 2013. Africans unite against new form of colonialism: no REDD+ Network born. No REDD+ in Africa Network. Available at: http://www.REDD+-monitor.org/2013/04/03/launch-of-no-REDD+in-africa-network-REDD+-could-cause-genocide/\#en

Bazaara, N. 2000. Civil society and the struggle for land rights for marginalised groups: the contribution of the Uganda Land Alliance to the Land Act 1998. Kampala: Centre For Basic Research.

Benjaminsen, T.A. and I. Bryceson. 2012. Conservation, green/blue grabbing and accumulation by dispossession in Tanzania. Journal of Peasant Studies 39(2): 335-355. Researchgate

Boehnert, J. 2015. The green economy: reconceptualising the natural commons as natural capital. Environmental Communication 10(4): 395-417.

Bond, P. 2011. Politics of climate justice: paralysis above, movement below. Presented to the Gyeongsang University Institute of Social Science, Jinju, 27 May.

Bond, P. 2013. Climate crisis, carbon market failure, and market booster failure: a reply to Robin Hahnel's 'Desperately seeking left politics unity on international climate policy'. Capitalism Nature Socialism 24 (1): $54-61$.

Borras, S.M. Jr. and J. Franco. 2013. Global land grabbing and political responses from below. Third World Quarterly 34: 1723-1747.

Bottazzi, P., D. Crespo, H.Soria, H.Dao, M.,Serrudo, J. Benavides, S. Schwarzer and S. Rist. 2013. Carbon sequestration in community forests: trade-offs, multiple outcomes and institutional diversity in the Bolivian Amazon. Development and Change 45(1): 105-131.

Bracking, S. 2015. The anti- of climate finance: the creation and performativity of the Green Climate Fund. Antipode 47(2): 281-302.

Brockington, D. 2002. Fortress conservation: the preservation of the Mkomazi Game Reserve, Tanzania. Oxford: James Currey.

Bumpus, A. 2011. The matter of carbon: understanding the materiality of $\mathrm{tCO}_{2} \mathrm{e}$ in carbon offsets. Antipode 43 (3): 612-638.

Büscher, B. 2013. Nature 2.0. Geoforum 44: 1-3.

Cavanagh, C.J. and T.A. Benjaminsen. 2014. Virtual nature, violent accumulation: the 'spectacular failure' of carbon offsetting at a Ugandan National Park. Geoforum 56: 55-65.

Cavanagh, C., P. Vedeld and L. Traedal, 2015. Securitising REDD+? Problematising the emerging illegal timber trade and forest carbon interface in East Africa, Geoforum 60: 72-82.

Climate Action Network International (CAN-I) Annual Report 2013. Lebanon: CANI.

Corson, C., B. Brady, A. Zuber, J. Lord and A. Kim. 2015. The right to resist: disciplining civil society at Rio +20. The Journal of Peasant Studies 42(3-4): 859-878.

Descheneau, P. and M. Peterson. 2011. Between desire and routine: assembling environment and finance in carbon markets. Antipode 43(3): 662-681.

Dryzek, J.S. 1997. The politics of the earth: environmental discourses. Oxford: Oxford University Press. 
Dryzek, J.S. 2000. Deliberative democracy and beyond: liberals, critics, contestations. Oxford: Oxford University Press.

Dryzek, J.S., D. Downes, C. Hunold, D. Schlosberg and H. Hernes. 2003. Green states and social movements: environmentalism in the United States, United Kingdom, Germany and Norway. Oxford: Oxford University Press.

Fairhead, J., M. Leach and I. Scoones. 2012. Green grabbing: a new appropriation of nature? The Journal of Peasant Studies 39(2):237-261.

German, L., A. Mandondo, F. Paumgarten and J. Mwitwa. 2014. Shifting rights, property and authority in the forest frontier: 'stakes' for local land users and citizens. The Journal of Peasant Studies 41(1): 51-78. Researchgate

Gingembre, M. 2015. Resistance or participation? Fighting against corporate land access amidst political uncertainty in Madagascar. The Journal of Peasant Studies 42(3-4): 561-584.

Grainger, M. and Geary, K. 2011. The New Forests Company and its Uganda plantations. Washington DC: OXFAM International.

Hall, R., Edelman, E., Borras Jr, S., Scoones, I., White, B. and Wolford, W. 2015. Resistance, acquiescence or incorporation? an introduction to land grabbing and political reactions 'from below. The Journal of Peasant Studies 42(3-4): 467-488.

Han, H. 2014. How organisations develop activists: civic Associations and leadership in the $21^{\text {st }}$ century. New York: Oxford University Press.

Health Poverty Action 2015. Honest accounts: the true story of Africa's billion dollar losses. Available: http://www.healthpovertyaction.org/wp-content/uploads/downloads/2014/07/Honest-Accountsreport-v4-web.pdf

Kandel, M. 2015. Politics from below? Small-, mid- and large-scale land dispossession in Teso, Uganda, and the relevance of scale The Journal of Peasant Studies 42(3-4): 635-652.

Lohmann, L. 2011. The endless algebra of climate markets. Capitalism Nature Socialism Vol. 22, No. 4, pp. 93-116.

Lyons, K. and P. Westoby. 2014. Carbon colonialism and the new land grab: plantation forestry in Uganda and its livelihood impacts. Journal of Rural Studies 36: 13-21.

Martinello, G. 2015. Social struggles in Uganda's Acholiland: understanding responses and resistance to Amuru Sugar Works. The Journal of Peasant Studies 42(3-4): 653-669.

Mbatu, R. 2016. REDD+ research: reviewing the literature, limitations and ways forward. Forest Policy and Economics 73: 140-152.

Mennie, W. 2013. Guest Post: REDD+ fails the world's forests and climate | REDD+-monitor.org. Available at: http://www.REDD+-monitor.org/2013/08/30/guest-post-REDD+-fails-the-worldsforests-and-climate [Accessed September 4 2013].

Miller, P. 1992. Accounting and objectivity: the invention of calculating selves and calculable spaces. Annals of Scholarship 9(1/2): 61-86.

Mol, A. 2000. The environmental movement in an era of ecological modernisation. Geoforu 31(1): 45-56.

Moyer, B., J. McAllister, M. Finley, and S. Soifer. 1991. Doing democracy: the MAP model for organising social movements. BC, Canada: New Society Publishers.

Mwangi, E. and A. Wardell. 2012. Multi-level governance of forest resources. International Journal of the Commons 6(2): 79-103.

Nel, A. and D. Hill. 2013. Constructing walls of carbon: the complexity of community, carbon sequestration and protected areas in Uganda. Journal of Contemporary African Studies 31(3): 421440. Researchgate

Nel, A. 2014. Sequestering market environmentalism: geographies of carbon forestry and unevenness in Uganda. PhD Thesis. Dunedin: University of Otago. 
Nel, A. 2015. Assembling value in carbon forestry: practices of assemblage, overflows and counterperformativities in Ugandan carbon forestry. Leverhulme Centre for the Study of Value Working Paper Series No 10. Available: http://thestudyofvalue.org/wp-content/uploads/2015/01/WP-10_Nel2015-Assembling-value-in-carbon-forestry.pdf

Nel, A. 2015. The neoliberalisation of forestry governance, market environmentalism and reterritorialisation in Uganda. Third World Quarterly 36(12): 2294-2315. Researchgate

New Forests Company 2011. New Forests Company: response to Oxfam. Available at: http://www.newforests.net/index.php/responsibility/response-to-oxfam [Accessed December 13 2011].

Nielsen, D.T. 2016. From REDD+ forests to green landscapes? Analysing the emerging integrated landscape approach discourse in the UNFCCC. Forest Policy and Economics 73: 177-184.

O'Brien, K. and R. Leichenko. 2010. Double exposure: assessing the impacts of climate change within the context of globalisation. Global Environmental Change 10(3): 221-232. Academia

Okereke, C. and K. Dooley. 2010. Principles of justice in approaches to avoided deforestation: towards a post-Kyoto climate agreement. Global Environmental Change 20: 82-95.

Oxfam America 2008. Turning carbon into gold. Oxfam Briefing Paper 123. Washington DC: Oxfam America.

Peters-Stanley, M., K. Hamilton and D. Yin 2012. Leveraging the landscape: state of the forest carbon markets 2012. Washington, D.C.: Ecosystem Marketplace.

Schroeder, H. and C. McDermott. 2014. Beyond Carbon: enabling justice and equity in REDD+ across levels of governance. Ecology and Society 19(1): 31.

Suiseeya, K. and S. Caplow. 2013. In pursuit of procedural justice: lessons from an analysis of 56 carbon project designs. Global Environmental Change 23: 968-979. Researchgate

Swyngedouw, E. 2005. Governance innovation and the citizen: the Janus face of governance-beyond-thestate. Urban Studies 43(11): 1991-2006.

Twesigye, B. 2008. Lessons from citizen activism in Uganda: saving Mabira Forest. SAIIA Occasional Papers Series No. 7. Johannesburg: South African Institute of International Affairs, University of Witwatersrand.

Uganda Carbon Bureau 2013. http://www.ugandacarbon.org/index.php accessed 25 Nov 2013.

Walbott, L. 2014. Indigenous peoples in UN REDD+ negotiations: "importing power" and lobbying for rights through discursive interplay management. Ecology and Society 19(1): 21.

Westoby, P. and K. Lyons. (forthcoming). The place of social learning and social movement in transformative learning: a case study of Sustainability Schools in Uganda. Journal of Transformative Education

Whelan, J. and K. Lyons. 2005. Community engagement or community action: choosing not to play the game. Environmental Politics 14(5): 596-610.

White, B., S.M. Borras Jr, R. Hall, I. Scoones, and W. Wolford. 2012. The new enclosures: critical perspectives on corporate land deals. Journal of Peasant Studies 39(3-4): 619-647. 